\title{
NON-DESTRUCTIVE CHARTER RESPONSES TO LEGISLATIVE INEQUALITIES
}

\author{
DALE GIBSON*
}

\begin{abstract}
S. 24 of the Charter bestows wide remedial discretion on the courts in the adjudication of Charter claims. Professor Gibson argues that this discretion must not be employed in a manner destructive of existing rights because s. 26 requires the preservation of such rights. He explains how non-destructive methods of Charter enforcement fall into two categories: interpretative and remedial. Non-destructive remedies would include mechanisms such as: selective striking out, utilizing s. 52(I), the imposing of a trust condition on a statutory beneficiary, reducing disruptive judicial intervention into the legislative domain through a positive 'reading in' of sufficient context to allow compliance with the Charter, the temporary application of $s$. I to justify a Charter violation until there is a reasonable opportunity to remedy the defect, conceivably the use of an order for the amendment of legislation violating the Charter, and finally, the employment of declaratory judgments to exert political pressure on the government to bring its legislation into compliance with the Charter.
\end{abstract}

\section{TABLE OF CONTENTS}

I. INTRODUCTION ....................... 181

II. NON-DESTRUCTIVE INTERPRETATION $\ldots \ldots \ldots \ldots \ldots 183$

III. NON-DESTRUCTIVE REMEDIES $\ldots \ldots \ldots \ldots \ldots \ldots \ldots .185$

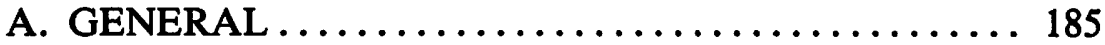

B. SELECTIVE STRIKING OUT $\ldots \ldots \ldots \ldots \ldots \ldots \ldots \ldots \ldots \ldots$

C. IMPOSING A TRUST OBLIGATION ......... 186

D. READING IN ........................ 187

E. TEMPORARY APPLICATION OF SECTION $1 \ldots \ldots, 188$

F. ORDER TO AMEND $\ldots \ldots \ldots \ldots \ldots \ldots \ldots \ldots \ldots \ldots . \ldots$

G. DECLARATORY JUDGMENT . . . . . . . . . . 189

IV. CONCLUSION ....................... 190

\section{INTRODUCTION}

The Canadian Charter of Rights and Freedoms ${ }^{1}$ bestows an extremely wide-ranging remedial discretion on courts called upon to adjudicate alleged violations of Charter rights. Like all potent weapons and tools, some of the more sweeping remedies can be injurious if not used with care. In some situations, in fact, certain Charter cures may be more harmful than the ills they are intended to remedy.

These problems arise most frequently in the context of equality claims. An illustration is provided by a Charter challenge to payment procedures

- Professor of Law, University of Manitoba; Belzberg Visiting Professor of Constitutional Studies, University of Alberta, 1988-1990.

1. Canadian Charter or Rights and Freedoms, as enacted in Canada Act 1982 (U.K.), c. 11. 
under the Family Allowances Act ${ }^{2}$ that has been attacked in the courts. ${ }^{3}$ It has been the practice, where separated parents have joint custody of their children, to make Family Allowance payments solely to the mother. This practice is thought by many to violate the father's right to equal benefit of the law under section 15(1) of the Charter. If this view were ultimately upheld by the courts, and if they chose to remedy the inequality by striking down the benefit for women, rather than by responding in a manner more likely to produce an equivalent benefit for men, the Charter challenge might well produce more harm than good. A similar risk of discarding the baby with the bath water arises whenever an equality attack under the Charter is launched against laws or practices that provide desirable social benefits to an unjustifiably restricted group of beneficiaries.

Such destructive responses to equality claims are not inevitable, however. I am of the opinion that the Charter not only permits non-destructive remedies; it requires them. This opinion is rooted in section 26 of the Charter:

The guarantee in this Charter of certain rights and freedoms shall not be construed as denying the existence of any other rights or freedoms that exist in Canada.

While it seems clear that this provision does not "constitutionalize" any rights that are not guaranteed by the Charter itself, ${ }^{4}$ this provision is much more than a mere interpretative guideline. Use of the mandatory phrase "shall not", prohibits construing any Charter right (including the equality guarantee) in a manner that would deny the existence of other existing rights.

It should be noted that the existing rights protected from Charter encroachment by section 26 are not restricted to constitutional rights. Whereas the equivalent section in the Canadian Bill of Rights (section 5(1)) refers to "any human right or fundamental freedom", section 26 of the Charter refers only to "any other rights or freedoms". A mother whose children meet the criteria set out in the Family Allowances Act has an undeniable legal right to receive an allowance under section 3(1) of the Act, which states, in part: ". . . there shall be paid out of the consolidated revenue fund for each month a family allowance . . . in respect of each child. . . ." Given the imperative nature of section 26 , it seems clear that courts must exercise their responsibilities under the Charter in a manner that will not deny rights currently enjoyed by female parents under the Family Allowances Act, or to favoured, but legally entitled, beneficiaries under other social schemes.

It has to be admitted that the courts do not yet appear to have acknowledged such a constraint in such situations. In Reference Re Family Benefits Act, ${ }^{\text {s }}$ for example, the Nova Scotia Appellate Division declared a

2. R.S.C. 1985 , c. F-1.

3. Vincer v. Canada (A.G.) (1987) 82 N.R. 352 (Fed. C.A.). The claim was dismissed on jurisdictional grounds unrelated to the merits by the Federal Court of Appeal. Leave to Appeal does not appear to have been sought, but the substantive issue is likely to find its way before the courts again before long.

4. Re Grope des Eleveurs de Volailles and Chicken Marketing Agency (1985) 14 D.L.R. (4th) 151 (F.C.T.D.); Leger v. City of Montreal (1986) 41 M.V.R. 85 (Que. C.A.).

5. (1986) 186 A.P.R. 338. 
statutory benefit for single-parent women to be inconsistent with section 15 because it offered no benefit for men in an equivalent position. There was no acknowledgement that existing benefits should be protected. While that decision, arising from a constitutional reference, is technically advisory only, and is therefore not binding, an earlier decision to the same effect, Phillips v. Social Assistance Appeal Board ${ }^{6}$ did contain a binding declaration of constitutional invalidity for the existing benefit. In the trial decision Mr. Justice Nunn expressly addressed the question of providing a positive benefit for the excluded category, rather than striking down that for the favoured category, and declined to do so. This refusal was based on his reluctance to "assume the role of legislator", especially in view of the fact that the provincial legislature was scheduled to meet the following day.' It should be noted, however, that Nunn J. did not find himself powerless to award a positive remedy; he was simply "unwilling" to grant one in the circumstances. That can fairly be construed as a simple exercise of his discretionary powers under section 24(1) of the Charter. If, on the other hand, the decision was based on a belief that judges lack the power to grant a less destructive remedy than was granted in that case, it is submitted that it was mistaken. Neither the trial judge nor the Appellate Division mentioned the requirements of section 26 of the Charter.

The better view is that because of section 26 , judges are under an obligation to employ methods of enforcing Charter rights that will derogate from existing rights to the least extent possible. Such nondestructive methods fall into two categories: interpretative and remedial. Each category will be examined below.

\section{NON-DESTRUCTIVE INTERPRETATION}

In many situations, the least intrusive way of ensuring that Charter requirements are met without causing undue peripheral damage will be to give the legislation granting the inequitably distributed benefit a generous, Charter-sensitive, interpretation. The Family Allowances Act problem outlined above is amenable to such an approach.

The authority for favouring female parents in joint custody situations is found in section 9(1) of the Regulations under the Act, which reads as follows:

9(1) Where payment of a family allowance is approved, the allowance shall be paid to the male parent where

(a) there is no female parent; or

(b) the female parent and male parent are living separate and apart and the male parent has, in fact, custody of the child. ${ }^{8}$

A court called upon to rule on the meaning of this regulation faces two constitutional obligations:

a) Section 15 of the Charter demands an interpretation that is consistent with "equal benefit of the law".

6. (1986) 176 A.P.R. 415 (N.S.S.C.); affg. (1987) 34 D.L.R. (4th) 633 (N.S. App. D.).

7. Id. at 417.

8. Family Allowances Act Regulations, C.R.C. 1978, c. 642. 
b) Section 26 of the Charter requires an interpretation that respects existing rights.

It is submitted that the language of the regulation is open to an interpretation which complies with both imperatives.

In the case of joint custody, it would appear that all the requirements of clause 9(1)(b) are met. The parents are living separate and apart, and the male parent does have custody of the child. Where custody is shared equally, the father has as much custody "in fact" as the mother.

The regulation would seem, therefore, to require payment of the allowance on a pro rata basis to both the female and male parents. Such an interpretation would fully comply with both section 15 and section 26 of the Charter. Little stretching of the language of the regulation would be required. Literally, the regulation might be read as requiring payment to the man alone where he has such custody, but such a construction would be as offensive to the Charter as that which benefits the woman alone. The only serious interpretative difficulty arises from the use of the singular expression "the allowance", which might not be thought to contemplate two allowances. The answer to that difficulty is that shared payments to each parent would not constitute separate allowances; it would simply involve a shared allocation of the single allowance.

A court would be free to adopt such a construction even if it were of the opinion that it would do some small violence to the literal meaning of the words of the regulation. The court would, indeed, be required to do so by the principle: ut res magis valeat quam pereat" (that the thing may rather have effect than be destroyed). Maxwell on the Interpretation of Statutes ${ }^{9}$ quotes the following statement from Nokes v. Doncaster: ${ }^{10}$

If the choice is between two interpretations, the narrower of which would fail to achieve the manifest purpose of the legislation, we should avoid a construction which would reduce the legislation to futility and should rather accept the bolder construction based on the view that Parliament would legislate only for the purpose of bringing about an effective result.

Odgers on Construction of Deeds and Statutes " comments on the use of the same principle:

The law is anxious to save a deed if possible. This is sometimes expressed in the maxim $u t$ res magis valeat quam pereat. If by any reasonable construction the intention of the parties can be arrived at and that intention carried out consistently with the rules of law, the court will take that course.

...

The above maxim has also been called in aid when a deed cannot take effect in the manner expressed by the parties owing to some rule of law. The courts will, if possible, construe it to carry the intention into effect in some other way. This is perhaps analogous to the cypres doctrine in trusts.

The analogy to the cy-pres doctrine mentioned by Odgers is interesting and, it is submitted, important in the constitutional context. While the cypres principle normally finds expression in charitable trust situations, it is a

9. (12th ed. 1969) at 45.

10. [1940] A.C. 1014 at 1022 (H.L.).

11. (5th ed. 1967) at 32,34 . 
much broader concept. It is submitted that it has a legitimate role to play in the interpretation of legislation affected by constitutional constraints. Black's Law Dictionary ${ }^{12}$ explains the principle, in part, as follows:

As near as (possible). The rule of cy-pres is a rule for the construction of instruments in equity, by which the intention of the party is carried out as near as may be, when it would be impossible or illegal to give it literal effect....

The cy-pres doctrine has sometimes even been employed to avoid a literal interpretation even when such an interpretation was not absolutely impossible. Snell's Principles of Equity ${ }^{13}$ explains that the word "impossible" has been "generously construed, and extended to cases where the consequences of carrying out the trust would be highly undesirable ...." The examples cited by Snell involve disregarding racially restrictive provisions in a trust, while otherwise complying with its general charitable purpose.

If it is accepted that a literal interpretation of section 9(1) would not permit payment to both parents, it would be "impossible or illegal" to comply literally with that section in circumstances where parents are separated and have joint custody of their children. Payment of the allowance solely to the mother contravenes the requirement that "the allowance shall be paid to the male parent where ... the female parent and male parent are living separate and apart and the male parent has, in fact, custody of the child." Payment to either the father or the mother alone would contravene section 15(1) of the Charter (unless justifiable under section 1 of the Charter, which is unlikely). Attempting to achieve equality by striking down the benefit altogether would violate section 26 of the Charter. In that situation of impossibility, it is submitted that the $u t$ res magis principle requires a judicial response analogous to the cy-pres doctrine: an interpretation that satisfies the purpose of the legislation as fully as possible without contravening either section 15 or section 26 of the Charter. Such an interpretation would involve either a single joint payment to both parents, or payment of half the allowance to each parent.

Similar interpretative approaches to other laws that bestow benefits in an uneven manner could avoid many constitutional controversies.

\section{NON-DESTRUCTIVE REMEDIES}

\section{A. GENERAL}

The great breadth of the remedial power bestowed on the courts by section 24(1) of the Charter has often been remarked. Courts of competent jurisdiction have the authority, in the case of Charter violations, to award "such remedy as the court considers appropriate and just in the circumstances." While the remedies granted may be restricted to those that would be within the power of the particular court apart from the Charter, such a restriction would create no difficulty for superior courts, whose inherent 
remedial power in matters within their jurisdiction is limited only by express statutory proscription. In the absence of such proscriptions, such courts may be as innovative as is "appropriate and just" in the remedies they choose to adopt. ${ }^{14}$

\section{B. SELECTIVE STRIKING OUT}

Section 52(1) of the Constitution Act, 1982, which authorizes the courts to strike down laws that violate the Constitution, calls for caution in the process. It states: ". . . any law that is inconsistent with the provisions of the Constitution is, to the extent of the inconsistency, of no force or effect." This is a constitutional direction to the courts to act conservatively when called upon to invalidate legislation; they must do so only to the extent that the legislation is inconsistent with someone's constitutional rights. Where a constitutional problem can be solved by selective judicial surgery, rather than by complete invalidation of a provision, therefore, the more limited approach should be adopted.

Suppose, for example, that a statute made it an offence for a "male person" to engage in acts of gross indecency. A court that found this law to offend section 15 of the Charter would be better advised to strike out the word "male" than to strike down the entire prohibition. This would not be judicial "activism"; it would on the contrary display as much deference to the legislative will as would be possible in the circumstances.

It must be acknowledged that Mr. Justice Nunn refused to engage in selective striking-out in the Phillips case, described above. He was invited by counsel to strike out certain words that qualified a man's right to benefits under the impugned legislation, but he expressed the view that this would be a "legislative" act, in which judges should not engage. On the facts of that particular case, it is submitted, this was a justifiable conclusion. The legislation was such that if the words in question had been excised, women would have been placed at a disadvantage, and if similar surgery had been carried out on the provisions relating to women, the entire nature of the legislation would have been seriously altered. Similar problems would arise if surgery were attempted in the Family Allowance situation.

Selective surgery is not a universal remedy, therefore. It must be used with restraint and with due regard for the appropriate respective roles of judges and legtislators. In some circumstances, however, it would permit a court to enforce the requirements of the Charter without causing undue legislative damage.

\section{IMPOSING A TRUST OBLIGATION}

At times it may be possible for courts to reach outside the realm of public law for remedies that satisfy Charter obligations in a non-destructive manner. The Family Allowance problem again affords a good illustration. 
If a court were unwilling to order Family Allowances to be paid jointly or in shares to separated parents with joint custody, it could at least order mothers to whom allowances are paid in such circumstances to hold half the payment in trust for the other parent.

A precedent for such a judicially-imposed trust condition (admittedly in very different circumstances) is Thornton v. Board of School Trustees, ${ }^{15}$ where the Supreme Court of Canada agreed unanimously to an award of tort damages which included a sum representing the value of gratuitous nursing services provided to the plaintiff by his mother, and which the Court ordered the plaintiff to accept in trust for his mother. Inasmuch as the Charter prohibits gender-based discrimination, if the Family Allowances $A c t$ were interpreted as meaning that payment must be made to the female parent, it seems reasonable to infer a trust responsibility on the part of the mother with respect to the father's share of the entitlement.

\section{READING IN}

Everyone agrees that courts should intrude as little as possible into the legislative sphere when carrying out their Charter responsibilities. One of the ramifications of this constraint is that where the constitutionality of legislation is challenged courts are usually better able to act negatively (striking down invalid legislation) than positively (creating or ordering the creation of constitutionally enacted benefits).

This is not necessarily always the case, however. I have contended previously that in certain circumstances it would be less intrusive into the legislative domain for courts to make small positive amendments to offending legislation than to strike down an otherwise beneficial legislative scheme. ${ }^{16}$ In the Phillips case, for example, Mr. Justice Nunn chose to invalidate a social welfare scheme benefitting women, rather than to extend it to men in similar circumstances by simply reading in the words "or father" after all references to "mother." It is submitted that this had a much more sweeping legislative result than reading in the words "or father" would have had. This is so because, given prevailing social and economic patterns, the numbers of men who would have qualified for the benefits in question if the right had been extended were much fewer than the numbers of women denied by the court a benefit the legislature intended them to have.

There is, in other words, no inherent reason why a positive judicial response to a constitutional problem should interfere more seriously with legislative prerogatives than a negative response. The question of undue interference in the legislative process is one that must be addressed pragmatically, and on a case-by-case basis.

In the Family Allowance matter, even more obviously than in the Phillips case, the conservative response, if the courts were unwilling to adopt one of

15. [1978] 1 W.W.R. 607 (S.C.C.).

16. See D. Gibson, The Law of the Charter: General Principles (1986) at 190-191; D. Gibson, "Canadian Equality Jurisprudence: Year One" in Mahoney and Martin (eds.) Equality and Judicial Neutrality (1987) at 145. 
the interpretative approaches outlined earlier, would be to read in a few words that would enable the legislation to comply with the Charter, and thereby avoid destroying part of an important social welfare scheme. All that would be required would be to read in the words "or an appropriate portion thereof" after the second occurrence of the word "allowance" in Regulation 9(1), and to read in the words "sole or joint" immediately before the word "custody" in the same subsection.

\section{E. TEMPORARY APPLICATION OF SECTION 1}

When courts are asked to determine whether violations of the Charter constitute "reasonable limits ... . demonstrably justified in a free and democratic society", under section 1 of the Charter, they normally consider whether this would be so if the violation in question were permanent. It is submitted, however, that it would be within the power of a court to determine that a certain law, which would not be justifiable on a permanent basis, might nevertheless satisfy section 1 temporarily, until the legislature or government had a reasonable opportunity to remedy the Charter defect.

If, with respect to Family Allowance problem, the courts found that discriminating against male parents with joint custody on a permanent basis violated section 15 of the Charter, it might nonetheless be open to them to hold that the temporary continuation of such a scheme until such time as a more equitable arrangement could be put in place, would be a reasonable limit in a free and democratic society. Surely it would be a more reasonable expedient than wiping out all Family Allowance in shared custody situations.

Judicial approval was expressed for a somewhat similar approach in $R e$ Paquette and The Queen (No. 2). ${ }^{17}$ The issue was whether the delayed proclamation in some provinces of Criminal Code provisions for Frenchlanguage criminal trials violated the equality rights of a Francophone accused in Alberta, where the provisions had not yet been proclaimed. The Alberta Court of Appeal ruled that there was no contravention of the Charter. Mr. Justice Stevenson commented, for the majority, that if a violation had occurred, a delayed remedy would have been appropriate: ${ }^{18}$

\footnotetext{
"Assuming a breach, the proper remedy would, in my view, be a declaration coupled, perhaps, with a requirement of proclamation but allowing an appropriate time for coming into force. I would not have ordered immediate implementation . . . ."
}

\section{F. ORDER TO AMEND}

If a court were not prepared to alter the Family Allowance legislation or Regulations on its own authority, it could, in the alternative, order the Governor-in-Council to make the amendments necessary to bring about Charter compliance. The Charter problem concerning parents with joint

17. (1987) 46 D.L.R. (4th) 81 at $99-100$ (Alta. C.A.).

18. Id. at 100 . 
custody lies, after all, in the Regulation, rather than in the statute. The statute empowers the Governor-in-Council to make regulations concerning the persons to whom allowances are to be paid, and the inequality complained of could be remedied by amendments like those suggested above to section 9(1) of the Regulations.

There can be no doubt that the Governor-in-Council is subject to the Charter. ${ }^{19}$ Although it has not yet been determined conclusively whether the Crown and those exercising Crown powers are subject to injunctions or mandatory orders where Charter violations are concerned, there is considerable support for the view that the Crown is subject to such relief, where appropriate. ${ }^{20}$ Rouleau J. of the Federal Court of Canada, Trial Division, stated in Levesque v. Attorney-General of Canada $a^{21}$ that the Crown is subject to mandamus in Charter matters, and the Alberta Court of Appeal indicated, in the above-quoted passage from the Paquette case, that it would be prepared, in an appropriate case, to order the Governorin-Council to issue a proclamation. While it might be considered an undue encroachment of legislative supremacy for a court to order Parliament or a provincial Legislature to alter their legislation (though it should be remembered that all constitutional constraints on legislation intrude on legislative supremacy, and an order to legislate would differ only in degree from intrusions that are incontestably permissible), there would not appear to be any obstacle to at least ordering an appropriate Minister of the Crown, such as the Attorney-General, to introduce an amending Bill in Parliament or the Legislature.

\section{G. DECLARATORY JUDGMENT}

Even if a court were not prepared to go so far as ordering that legislative amendments be enacted or introduced, it could achieve much the same result, for practical purposes, by means of the thoroughly orthodox technique of issuing a declaratory judgment. ${ }^{22}$ The Crown is unquestionably subject to declaratory judgments..$^{23}$ While a judicial declaration that the Crown has a constitutional duty to amend a regulation, or that a certain statute will violate the Constitution until amended by the appropriate legislative body, would not impose a legal obligation on anyone, the political pressure it would exert on the government in question to carry out the responsibility the court declared would assure compliance in most instances.

The results would not be instantaneous, as they would be if the court were prepared to deal with the problem by interpretation, selective surgery, or reading in, but at least the devastation of wholesale invalidation would be avoided. New entitlements could be made retroactive, or not, depending upon the equities and practicalities of the situation.

19. Operation Dismantle Inc. v. The Queen (1985) 18 D.L.R. (4th) 481 (S.C.C.).

20. See D. Gibson, supra n. 16 at 206 , and authorities cited therein.

21. (1985) 25 D.L.R. (4th) 184.

22. See L. Sarna, The Law of Declaratory Judgments (2nd ed. 1988).

23. P. Hogg, Liability of the Crown (1971) at 18. 
A declaration could be used in tandem with a finding of temporary validity under section 1 of the Charter. In the case of the impugned Family Allowance payment procedure, for example, a court could declare that section 9(1) of the Regulations is a "reasonable limit" on fathers' rights to equal treatment until the Government has had an opportunity to bring the regulation into compliance with section 15 of the Charter, but only until then. Given the fact that only a regulation is involved, and the Government would therefore not need to set a full Parliamentary response in motion, the appropriate period of temporary validity would be short in that case. While courts employing this technique would not have to specify the length of the validation period in advance, it would be desirable to do so, at least in relatively simple situations like those involved in the Family Allowance illustration.

\section{CONCLUSION}

Section 26 of the Charter not only permits but requires non-destructive responses to equality challenges under the Charter. Section 24(1) gives courts a sufficiently wide remedial discretion to avoid undue destructiveness in most situations. Several techniques, both interpretative and remedial, by which equality rights can be enforced in a non-destructive manner, have been outlined above.

Some of the suggested responses may seem radical to judges concerned about over-stepping the bounds of proper judicial action. Several of the techniques discussed are so orthodox and unintrusive, however, that they should commend themselves to the most diffident of judges. But it is essential to realize is that even the most novel of the non-destructive approaches discussed in this paper would ultimately be more conservative than totally striking down legislation that distributes needed benefits unevenly, and thereby demolishing desirable schemes of social welfare created by the peoples' elected representatives. Throwing babies out with bathwater is radicalism at its worst. 